\title{
Performance of soybean cultivars in integrated pest management in lowland agroecosystem
}

\author{
Fabrício Oliveira Fernandes ${ }^{1} \oplus$, Ana Paula Afonso da Rosa ${ }^{2} \oplus$, Jéssica Ávila de Abreu$^{3} \oplus$,

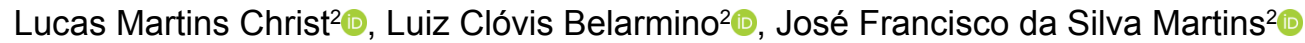

\footnotetext{
1 Universidade Estadual Paulista Júlio de Mesquita Filho, Jaboticabal-SP, Brasil. E-mail: fabriciof9@gmail.com

2Embrapa Clima Temperado, Pelotas-RS, Brasil. E-mail: ana.afonso@embrapa.br; lucasmchrist@gmail.com; luiz.belarmino@embrapa.br; jose.martins@embrapa.br

${ }^{3}$ Universidade Federal de Pelotas, Pelotas-RS, Brasil. E-mail: jessica.abreu91@gmail.com
}

ABSTRACT: Soybean crop represents a large economic share in the Brazilian agricultural production. In Rio Grande do Sul (RS), with each new crop cycle there is an increase in the area under cultivation. In the lowland environment, the crop covers 5.4 million hectares, corresponding to about $20 \%$ of the State total area. Using transgenic cultivars whose main advantage is controlling target insects, as well as the reduced number of insecticide applications throughout the crop can be a viable alternative. However, the high cost of transgenic seed is considered as the main disadvantage in adopting this technology. The objective of this study was to evaluate the performance of cultivars RR1 and RR2 in relation to the occurrence of caterpillars and stink bugs, as well as to evaluate the production cost. The experiment was set up at Embrapa Clima Temperado in the crop seasons of 2014/2015 and 2015/2016, with conventional cultivars (BMX Potência (RR1 6.7)) and Bt isolines (BMX Ponta (IPRO 6.6)) and BMX Vanguarda (IPRO 6.0)). BMX Potência cultivar showed a higher incidence of defoliating caterpillars and Nezara viridula stinkbug, but it is the most indicated cultivar, among those evaluated, for the south lowland environment of RS, due to its yield and profitability.

\section{Desempenho de cultivares de soja no manejo integrado de pragas no agroecossistema de terras baixas}

RESUMO: A cultura da soja representa grande parcela no Valor Bruto da Produção agrícola brasileira. No Rio Grande do Sul, a área utilizada foi de 5,4 milhões de ha, enquanto nos territórios de Terras Baixas de clima temperado a área de cultivo mais que triplicou na última década e consiste em promissora fronteira agrícola. $O$ uso de cultivares transgênicas que tem como principal vantagem o controle de insetos alvo, além da redução do número de aplicações de inseticidas ao longo do cultivo. Porém, 0 alto custo do valor da semente transgênica é considerado a principal desvantagem na adoção dessa tecnologia. 0 objetivo deste trabalho foi avaliar o desempenho de cultivares RR1 e RR2 em relação à ocorrência de lagartas e percevejos, bem como avaliar o custo de produção. O experimento foi instalado na Embrapa Clima Temperado nas safras 2014/2015 e 2015/2016 com as cultivares convencional (BMX Potência (RR1 6.7)) e as isolinhas Bt (BMX Ponta (IPRO 6.6) e BMX Vanguarda (IPRO 6.0)). A cultivar BMX Potência apresentou maior incidência de lagartas desfolhadoras e o do percevejo Nezara viridula, sendo a cultivar mais indicada, entre as avaliadas, para o ambiente de terras baixas do Sul do RS, devido à produtividade e lucratividade.

Palavras-chave: lagartas desfolhadoras; análise econômica; percevejo-da-soja 


\section{Introduction}

Soy [Glycine max (L.) MERRILL] is one of the main crops of Brazilian agribusiness. Until the 1960s, its cultivation was restricted only to high latitudes areas, due to photoperiod sensitivity, therefore, the southern Brazil, especially Rio Grande do Sul (RS), held most of the national production. Implementation of soybean breeding programs in Brazil made this crop cultivation in low latitudes possible, through the development of more adapted cultivars, by the incorporation of genes that delay the crop flowering, even under conditions of inductive photoperiod. Thereby, it also made possible the long juvenile period characteristic, with the crop expansion at a significant level in Santa Catarina, Paraná, São Paulo, Mato Grosso do Sul, Minas Gerais and Goiás (Knorr, 2017).

In Rio Grande do Sul (RS), the lowlands cover 5.4 million hectares, corresponding to about $20 \%$ of the State total area (Pinto et al., 2017). With each harvest, an increase in the area occupied by the soybean cultivation can be verified. According to data from Rio Grandense Rice Institute (Irga), the soybean rotation with irrigated rice occupied 270,358 hectares of lowland in the 2015/2016 crop (Irga, 2017).

In soybean cultivation, pest insects can strike during all phenological stages. From the vegetative to early reproductive stages (formation of pods) the defoliating caterpillars, Anticarsia gemmatalis (Hübner, 1818) (Lepidoptera: Noctuidae) and Chrysodeixis includens (Walker, 1858) (Lepidoptera: Noctuidae) predominate. The feeding habit of both causes a reduction in leaf area, thus interfering with the photosynthetic capacity of the plant (Moscardi et al., 2012).

Phytophagous stink bugs predominate in more advanced stages of the soybean crop, from formation of pods to the end of seed development (R3 to R7), a moment at which seed yield and quality are defined (Mattioni et al., 2015).

Due to the high occurrence of these pest insects, the possibility of using genetically modified plants with genes that confer resistance to them began to be taken into consideration. The most current event is MON 87701 (Cry1Ac) X MON 89788 (cp4 epsps), which provides glyphosate tolerance during weed management in the soybean crop. This event also presents the $B t$ gene insertion, a strategy for controlling the velvetbean caterpillar (A. gemmatalis), soybean looper ( $C$. includens), tobacco budworm [(Heliothis virescens) (Fabricius, 1781) (Lepidoptera: Noctuidae)] and the bean shoot moth [(Crocidosema aporema) (Walsingham, 1914)) (Lepidoptera: Tortricidae)]; in addition, it suppresses the lesser cornstalk borer caterpillar [Elasmopalpus lignosellus (Zeller, 1848) (Lepidoptera: Pyralidae)], Helicoverpa spp. [Helicoverpa zea (Boddie, 1850) (Lepidoptera: Noctuidae) and Helicoverpa armigera (Hunber, 1805) (Lepidoptera: Noctuidae)] (CTNBio, 2017).

Introducing cultivars that expresses Cry1Ac protein in soy provides a reduction in the density of $A$. gemmatalis and $C$. inclusens in relation to non-transgenic genotypes, contributing to the integrated pest management (IPM) in the crop. Laboratory studies showed that treatments containing
Cry1Ac protein have been classified as resistant to the artificial infestation of $A$. gemmatalis and $C$. includens, from a susceptible population, due to the high dosage of the Cry1Ac protein (Bernardi et al., 2016).

Use of transgenic cultivars has as main advantage the reduction in the number of insecticide applications for lepidopteran control (Miguel et al., 2014). However, the transgenic seed cost is higher when in comparison to cultivars that do not have Bt proteins (Santos et al., 2017). This said factor, dependent on the region edafoclimatic conditions, the technological level used in management, and the profit margin envisioned by the producer, may be decisive for employing the technology (Richetti, 2016).

With the introduction of lepidoptera-resistant cultivars in the market (James, 2012) it is necessary to study the performance of these materials in field, since for some cultivars this information is still scarce. The aim with this study was to evaluate the performance of cultivars RR1 and RR2 in relation to the occurrence of defoliating caterpillars and stink bugs, as well as to evaluate the production cost for the lowland agroecosystem.

\section{Materials and Methods}

Two experiments were set up in the Lowlands Experimental Station from Embrapa Temperate Climate, in the 2014/2015 and 2015/2016 crops. The soil in the region is classified as Haplic Planosol (Embrapa), which is characterized by a shallow, grayish, clayey soil that has an impermeable B horizon (Santos et al., 2013). Population density used for the crop was of 250,000 ha $^{-1}$ plants, with a spacing of 0.40 meters between rows, on plots five meters long.

Occurrence of defoliating caterpillars, in addition to the presence of stink bugs, were evaluated in the conventional BMX Potência (RR1 6.7) cultivars and in the $B t$ isolines BMX Ponta (IPRO 6.6) and BMX Vanguarda (IPRO 6.0) that had the Cry1Ac protein.

In the 2014/2015 crop, soybean cultivars were sown on $29 / 11 / 2014$ with emergence on $08 / 12 / 2015$, and in the $2015 / 2016$ crop the sowing was carried out on $04 / 12 / 2015$, with emergence on $23 / 12 / 2015$.

The number of defoliating caterpillars and stink bugs was evaluated by employing the "pano-de-batidas" (shaking) method. The positioning was between the central rows (four and five), with 3 shakes in the two rows of each plot, having a total of 2 samples per plot (Boyer \& Dumas, 1969), totaling 40 plots per cultivar. Evaluations of the occurrence of insects were carried out in the vegetative and reproductive stages during the two crop cycles.

For yield evaluation, plants were manually harvested, with the two central rows (four and five) of each plot removed. The grains were then separated from the straw and dried at 40 ${ }^{\circ} \mathrm{C}$ until they reached $13 \%$ humidity. Afterwards, they were weighed in balance (Urano Comercial Pop-z) and the humidity was measured through the humidity meter (Multigrain/ Agrosystem). From the obtained data, it was possible 
calculating the yield of each cultivar, by using the following formula: Yield $=[100-\mathrm{RH}(\%)] \times \mathrm{W}(\mathrm{Kg}) * 1000 /(100-13) \times$ $\mathrm{RP} / 10)$. Where: $\mathrm{RH}(\%)=$ relative humidity of the grains after drying; $\mathrm{W}(\mathrm{Kg})=$ weight of the grains; $\mathrm{RP}=$ replicates.

The experimental design used was random blocks with four replicates and the data were transformed into $\sqrt{ } x+0.5$ due to the heterogeneity of the variances (Hartley test). Results were analyzed by the Tukey test $(p<0.05)$ using the Genes program (Cruz, 2013).

From the technical coefficients, for economic analysis, the partial budget method was employed, according to the formula for processing economic analysis from reference data (Agrianual, 2016).

For the standard cost of inputs and services in the soybean crop implementation, conventional cultivars and $B t$ isolines, it was used the following formula: $F V=U V \times Q$. Where: $F V=$ final value; UV = unit value; $Q=$ quantity used of each input or service.

Production cost and economic indexes were elaborated according to Scorvo Filho et al. (2004) and the total cost per bag of $60 \mathrm{~kg}$ of soy, revenue ( $\left.\mathrm{R} \$ \mathrm{ha}^{-1}\right)$, average price ( $\mathrm{R} \$ \mathrm{sc}^{-1}$ $60 \mathrm{Kg})$ and profitability $\left(\mathrm{R} \$ \mathrm{ha}^{-1}\right)$ of soybean were calculated.

\section{Results and Discussion}

In the 2014/2015 and 2015/2016 crops, the average number of defoliating caterpillars collected per shaking during the soybean crop development period, from the emergence

A.

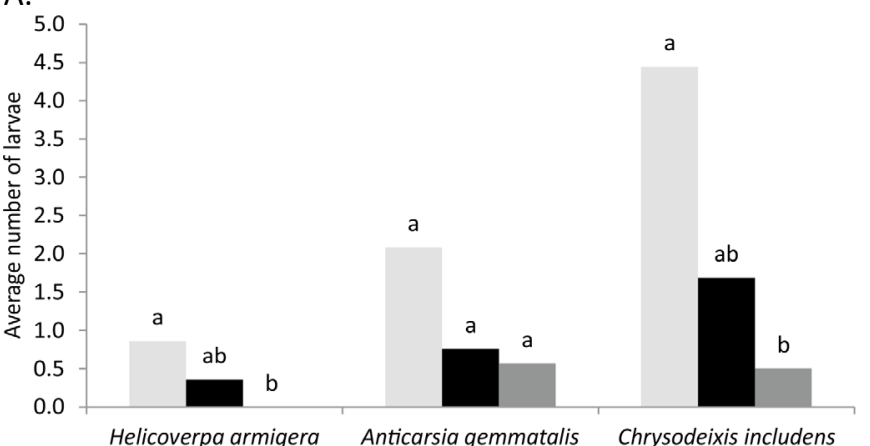
Larvae

BMX Potência (RR1 6.7) — BMX Vanguarda (IPRO 6.0) BMX Ponta (IPRO 6.6)

C.

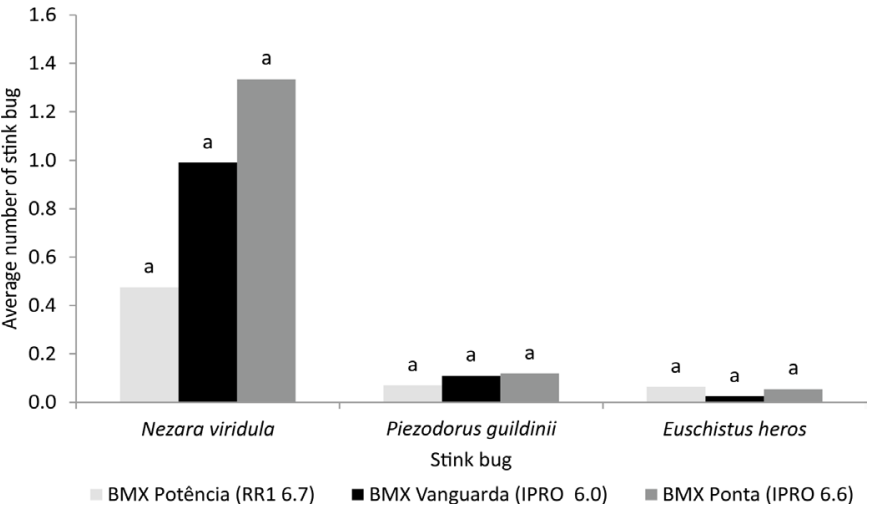

to the beginning of the reproductive period, was low in each one of the evaluated cultivars (Figure $1 \mathrm{~A}$ and $\mathrm{B}$ ). The level of control adopted was $20 \mathrm{~m}^{-1}$ caterpillars or $30 \%$ defoliation (Oliveira \& Rosa, 2014). Therefore, due to the lower number of caterpillars, and consequently lower defoliation, no chemical control was performed.

Caterpillars that had significant occurrence were $H$. armigera and $C$. included in the BMX Potência cultivar, regardless of the crop cycle, which is expected, since the cultivar does not have Bt protein (Wille et al., 2017). Among the $B t$ protein cultivars, BMX Ponta deserves mention, due to the lower occurrence of pest insects during both crop cycles (Figures $1 \mathrm{~A}$ and $\mathrm{B}$ ). In the conventional cultivar, there was a higher occurrence of caterpillars, a fact due the susceptibility.

Throughout the cultivars cycle, the presence of defoliating caterpillars from several instars was observed. However, in transgenic cultivars, because they have Cry1Ac proteins, a greater number of caterpillars, of up to the third instar, were observed feeding on the crop leaves (Bravo et al., 2017). Caterpillars from early instars cannot develop in transgenic events in the same way as in conventional cultivars.

In the 2014/2015 crop, the presence of $H$. armigera was verified in the area, but the same did not occur in the following crop, with the absence of this pest insect. Climatic conditions in these two evaluated crops were not favorable to the crop development, with rainfall above average due to the El Niño phenomenon. Thereby, climatic differences may

B.

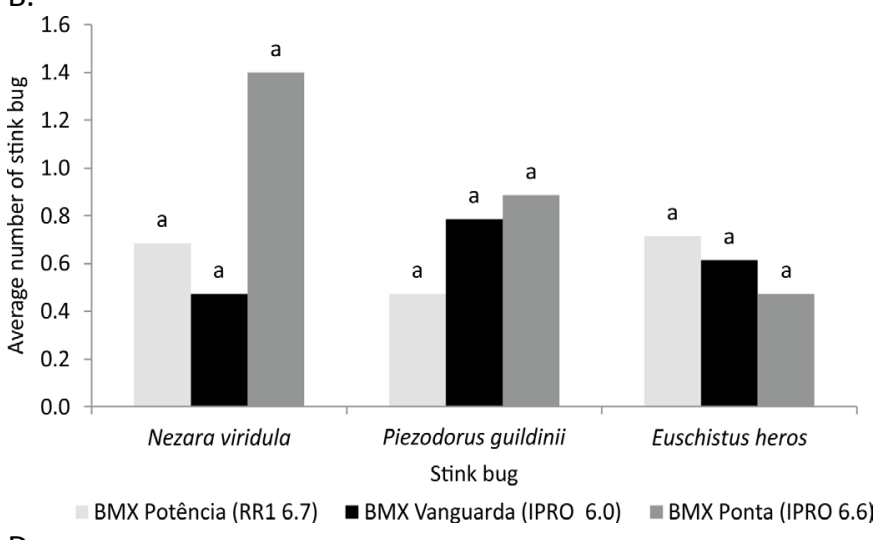

D.

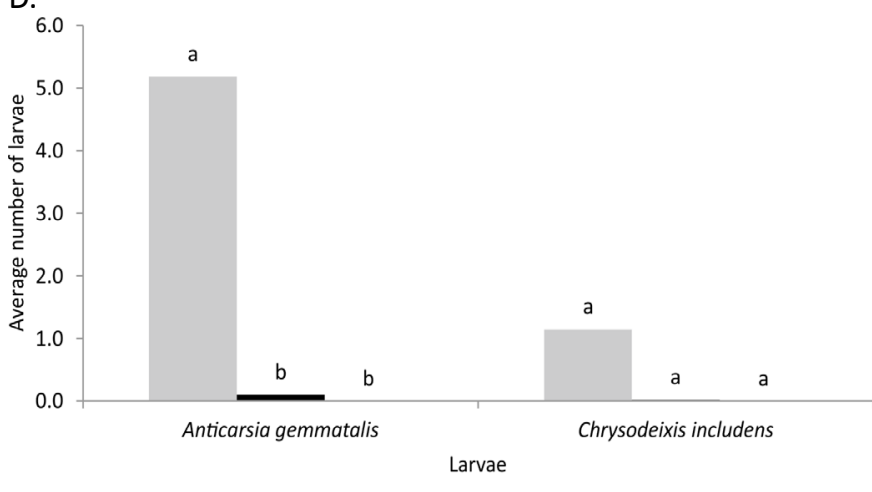

$\because \mathrm{BMX}$ Potência (RR1 6.7) $\quad \mathrm{BMX}$ Vanguarda (IPRO 6.0) $\square \mathrm{BMX}$ Ponta (IPRO 6.6)

Figure 1. Mean number of caterpillars ( $A$ and $B$ ) and stink bugs ( $C$ and $D$ ) sampled in soybean in the cultivars BMX Potência - D (RR1 6.7), BMX Vanguarda (IPRO 6.0) and BMX Ponta - I (IPRO 6.6) in the 2014/2015 and 2015/2016 crops. 
promote the presence or absence of defoliating caterpillars (Ciiagro, 2018), as occurred with the species H. armigera in the $2015 / 2016$ crop.

In the 2014/2015 crop (Figure 1A); C. inclusens was the species with the highest incidence during the entire crop cycle. The increased occurrence of $C$. includens may be associated with the rising number of fungicide applications in soybean crop for controlling of Asian rust [(Phakopsora pachyrhizi, Syd. \& P. Syd]. These products have an effect on entomopathogenic fungi that cause white (Nomuraea rileyi) or brown disease (Pandora sp. and Zoophthora sp.). Due to it, they act as agents of biological control of the soybean looper, keeping the population in balance, by epizootics (Sosa-Gómez et al., 2003). In the 2015/2016 crop (Figure 1B), the highest occurrence of $A$. gemmatalis caterpillars was verified.

Usage of conventional and genetically modified soybean cultivars promotes the alteration in the occurrence and alternation of species of pest insects and natural enemies (Brondani et al., 2008), corroborating with the results obtained in this study, where the highest occurrence of defoliation caterpillars, regardless of species, was in the material that did not have the $B t$ gene in its constitution.

Occurrence of stink bugs in the two evaluated crops was lower than the damage level of 4 stink bugs per shaking (Hoffmann-Campo et al., 2000); however, this situation was verified for all evaluated cultivars (Figures $1 \mathrm{C}$ and 1D). Stink bug management is no different for conventional soybean, RR soybean, and RR2 soybean. Soybean cultivars expressing the $B t$ gene do not present a control effect for all primary pests that cause damage to the crop in the different periods of its development, where among them the bean and pod sucking stink bugs stand out.

The most abundant species present in the samples were $N$. viridula, $P$. guildinii and $E$. heros, and in both crops the predominant species was $N$. viridula (Figures $1 C$ and 1D). The three species found, constitute a complex of stink bugs that pose a risk to the crop, since their attack causes malformation of pods and grains, leading to leaf retention (Sosa-Goméz \& Moscardi, 1995).

The predominance of a certain stink bug species is conditioned on its adaptation to the climate. Studies show that N. viridula predominates in southern Brazil (HoffmannCampo et al., 2000), P. guildinii in the northern Rio Grande do Sul, also in Tocantins and Mato Grosso, while in Paraná, $E$. heros is the most frequent of the soybeam suckers bugs (Nunes \& Corrêa-Ferreira, 2002).
The yield reached in the $2015 / 2016$ crop was $3,879.28$, $3,654.02$ and 3,791.46 $\mathrm{kg} \mathrm{ha}^{-1}$ for the cultivars BMX Potência, BMX Vanguarda IPRO and BMX Ponta IPRO, respectively (Table 1 ). This yield is in accordance with the average found in the region contemplated bythe study (REC 101) (Oliveira \& Rosa, 2014). However, lower yields have already been observed for these cultivars (Finoto et al., 2015), demonstrating that each cultivar expresses its productive potential differently according to the region they best adapts. It was not possible to evaluate yield in the $2014 / 2015$ crop due to the excessive rainfall during the harvest period.

When evaluating production costs using transgenic and conventional cultivars, it was observed that only after harvesting there was equivalence in the use of cultivars, with a cost of $\mathrm{R} \$ 96.80$ ton $^{-1}$.

The conventional cultivar BMX Potência was the one that had the highest profitability (R\$3089.94 ha-1), followed by BMX Ponta (R\$ 2998.18 $\mathrm{ha}^{-1}$ ) and BMX Vanguarda (R\$ $2849.31 \mathrm{ha}^{-1}$ ) (Table 2). This is because there was no need for insecticide application in the area, due to the low incidence of insects during the experiment. In terms of yield, BMX Potência cultivar produced $5.8 \%$ more than BMX Vanguarda cultivar and $2.3 \%$ more than BMX Ponta cultivar. Therefore, more studies on the economic profitability of soybean cultivation need to be conducted, mainly considering the cost of applying agrochemicals. Studies conducted in the 2016/2017 crop indicated that the cost of RR2 soybean production is higher than the implementation cost of the RR1, where this is mainly due to the price of seeds, in which is included the technological tax (Richetti, 2016).

Several factors can interfere with the level and variation of profitability in a production system, with the economic parameters and chemical control through the application of insecticides standing out and having direct influence, hence they must be predicted, quantified and monitored for greater control of the production costs.

Table 1. Yield in $\mathrm{Kg} \mathrm{ha}^{-1}$ for the cultivars BMX Potência - D (RR1 6.7), BMX Vanguarda (IPRO 6.0) and BMX Ponta - I (IPRO 6.6) in the $2015 / 2016$ crop.

\begin{tabular}{lc}
\hline \multicolumn{1}{c}{ Cultivars } & Yield $\left(\mathrm{kg} \mathrm{ha}^{-1}\right)$ \\
\hline BMX Potência - D (RR1 6.7) & $3,879.28 \pm 102.29 \mathrm{a}$ \\
BMX Vanguarda (IPRO 6.0) & $3,654.02 \pm 108.95 \mathrm{a}$ \\
BMX Ponta - I (IPRO 6.6) & $3,791.46 \pm 127.38 \mathrm{a}$ \\
Coefficient of Variation (\%) & 20.01 \\
\hline
\end{tabular}

Means followed by the same lowercase letter do not significantly differ by the Tukey test $(p<0.05)$.

Table 2. Economic evaluation of the RR1 and RR2 soybean crops in the 2015/2016 crop.

\begin{tabular}{lccc}
\hline \multirow{2}{*}{ Parameters } & \multicolumn{3}{c}{ Cultivars } \\
\cline { 2 - 4 } & BMX Potência - D (RR1 6.7) & BMX Vanguarda (IPRO 6.0) & BMX Ponta - I (IPRO 6.6) \\
\hline Total Cost $\left(\mathrm{R} \$ \mathrm{ha}^{-1}\right)$ & $1,111.96$ & $1,108.60$ & $1,108.60$ \\
Total Cost $\left(\mathrm{R} \$ \mathrm{sc}^{-1} 60 \mathrm{Kg}\right)$ & 17.20 & 18.20 & 17.54 \\
Revenue $\left(\mathrm{R} \$ \mathrm{ha}^{-1}\right)$ & $4,201.91$ & $3,957.91$ & $4,106.78$ \\
Mean Price $\left(\mathrm{R} \$ \mathrm{sc}^{-1} 60 \mathrm{~kg}\right)$ & 64.99 & 64.99 & 64.99 \\
Profit $\left(\mathrm{R} \$ \mathrm{ha}^{-1}\right)$ & $3,089.94$ & $2,849.31$ & $2,998.18$ \\
\hline
\end{tabular}




\section{Conclusion}

BMX Potência cultivar had a higher incidence of defoliating caterpillars and of the Nezara viridula stink bug; however it is the most indicated cultivar due to its herbivory support capacity for the lowland environment of southern RS, as well as due to its yield and profitability, when the chemical control application is not necessary.

\section{Literature Cited}

Agrianual 2016. Anuário da Agricultura Brasileira. São Paulo: FNP, 2016. 482p.

Bernardi, D.; Bernardi, O.; Horikoshi, R. J.; Salmeron, E.; Okuma, D. M.; Omoto, C. Biological activity of $B t$ proteins expressed in different structures of transgenic corn against Spodoptera frugiperda. Ciência Rural, v. 46, n.6, p. 1019-1024, 2016. https:// doi.org/10.1590/0103-8478cr20150047.

Boyer, W. P.; Dumas, B. A. Plant shaking methods for soybean insect survey in Arkansas. In: Boyer, W. P.; Dumas, B. A. (Eds.). Survey methods for some economic insects. Arkansas: Department of Agriculture Agricultural Research Service, 1969. p.92-94.

Bravo, A.; Gill, S. S.; Soberón, M. Bacillus thuringiens: a story of a successful bioinsecticide, Insect Biochemistry and Molecular Biology, v. 41, n.7, p. 423-431, 2011. https://doi.org/10.1016/j. ibmb.2011.02.006.

Brondani, D.; Guedes, J. V. C.; Farias, J. R.; Bigolin, M.; Karlec, F.; Lopes, S. J. Ocorrência de insetos na parte aérea da soja em função do manejo de plantas daninhas em cultivar convencional e geneticamente modificada resistente a glyphosate. Ciência Rural, v.38, n.8, p.2132-2137, 2008. https://doi.org/10.1590/ S0103-84782008000800007.

Centro Integrado de Informações Agrometeorológicas - Ciiagro, Manejo agrometeorológico de pragas e doenças visando aplicação de agroquímicos - uma análise preliminar. http:// www.ciiagro.sp.gov.br/pragas.html. 17 Jan. 2018.

Comissão Técnica Nacional de Biossegurança - CTNBio. Liberações comerciais. Plantas - Soja. Liberação comercial de soja geneticamente modificada resistente a insetos e tolerante a herbicida, Soja MON 87701 x MON 89788 - Processo no 01200.001864/2009-00. http://ctnbio.mcti.gov.br/liberacaocomercial\#/liberacao-comercial/consultar-processo. 25 Jan. 2018.

Cruz, C. D. GENES - a software package for analysis in experimental statistics and quantitative genetics.Acta Scientiarum. Agronomy, v.35, n.3, p.271-276, 2013. https://doi.org/10.4025/actasciagron. v35i3.

Finoto, E. L.; Miguel, L. Z. M.; Cordeiro Jr.; Paula, L.; Soares, M. B. B.; Bolanhezi, D. Avaliação de genótipos de soja RR e intacta RR2 Pro ${ }^{\circ}$ em semeadura direta na reforma de cana crua. Ciência \& Tecnologia, v. 7, n. especial, 2015.

Hoffmann-Campo, C. B.; Moscardi, F.; Corrêa-Ferreira, B. S.; Oliveira, L. J.; SOSA-Gómez, D. R.; Panizzi, A. R.; Corso, I. C.; Gazzoni, D. L.; Oliveira, E. B. Pragas da soja no Brasil e seu manejo integrado. Londrina: Embrapa Soja, 2000. 70 p. (Embrapa Soja. Circular Técnica, 30). http://ainfo.cnptia.embrapa.br/digital/bitstream/ item/128003/1/ID-6173.pdf. 22 Mar. 2018.
Instituto Riograndense do Arroz - Irga. Soja em rotação com arroz. http://www.irga.rs.gov.br/upload/20141210160340soja_em_ rotacao_com_arroz.pdf. 10 Mai. 2017.

James, C. Global status of commercialized Biotech/GM crops: 2014. Ithaca: ISAAA, 2014. 23p. (ISAAA. Brief, 49).

Knorr, M. T. Quarenta anos de expansão da soja no Brasil, 19752015. Confins, n. 33, p. 23-27, 2017. https://doi.org/10.4000/ confins.12592.

Mattioni, N. M.; Huth, C.; Segalin, S. R.; Mertz, L. M.; Russi, N.U. Distribuição espacial de danos de percevejo em campos de produção de sementes de soja. Interciencia, v 40, n. 1 , p. 50-56, 2015. https://www.interciencia.net/wp-content/ uploads/2017/10/50-MATTIONI-40-01.pdf. 19 Ago. 2019.

Miguel, F. B.; Esperancini, M. S. T.; Grizotto, R. K. Rentabilidade e risco da produção de milho safrinha geneticamente modificado e convencional na região de Guaíra/SP. Energia na Agricultura, v. 29, n. 1, p. 64-75, 2014. https://doi.org/10.17224/ EnergAgric.2014v29n1p64-75.

Moscardi, F.; Bueno, A. F.; Sosa-Gómez, D. R.; Roggia, S.; HoffmanCampo, C. B.; Pomari, A. F.; Corso, I. V.; Yano, S. A. C. Artrópodes que atacam as folhas da soja. In: Hoffman-Campo, C. B.; CorrêaFerreira, B. S.; Moscardi, F. (Eds.). Soja: manejo integrado de insetos e outros artrópodes-praga. Brasília: Embrapa, p.213309, 2012.

Nunes, M. C.; Corrêa-Ferreira, B. S. Danos causados à soja por adultos de Euschistus heros (Fabricius) (Hemiptera: Pentatomidae), sadios e parasitados por Hexacladia smithii Ashmead (Hymenoptera: Encyrtidae). Neotropical Entomology, v. 31 , n. 1, p. 109- 113, 2002. https://doi.org/10.1590/S1519566X2002000100015.

Oliveira, A. C. B. de; Rosa, A. P. S. A. da (Eds.). Indicações técnicas para a cultura da soja no Rio Grande do Sul e em Santa Catarina, safras 2014/2015 e 2015/2016. Pelotas: Embrapa Clima Temperado, 2014. 124p. (Embrapa Clima Temperado. Documentos, 382). http://ainfo.cnptia.embrapa.br/digital/ bitstream/item/120121/1/Indicacoes-Tecnicas-Embrapa-003. pdf. 19 Mar. 2018.

Pinto, L. F. S.; Miguel, P.; Pauletto, E. A. Solos de várzea e terras baixas. In: Emygdio, B. M.; Rosa, A. P. S. A.; Oliveira, A. C. B (Eds.). Cultivo de soja e milho em terras baixas do Rio Grande do Sul. Brasília: Embrapa, 2017. p. 23-43.

Richetti, A. Viabilidade econômica da cultura da soja na safra 2016/2017, em Mato Grosso do Sul. Dourados: Embrapa Agropecuária Oeste, 2016. 5 p. (Embrapa Agropecuária Oeste: Comunicado Técnico, 211). https://ainfo.cnptia.embrapa.br/ digital/bitstream/item/146045/1/СОT2016211.pdf. 19 Mar. 2018.

Santos, C. G.; Martins, G. L. M.; Silva, P. A.; Zoz, T. Custo de produção de soja transgênica em sistema de semeadura direta em São Desidério-BA. Revista de Agricultura Neotropical, v. 4, n. 2, p. 96-101, 2017. https://doi.org/10.32404/rean.v4i2.1430.

Santos, H. G. dos; Jacomine, P. K. T.; Anjos, L. H. C. dos; Oliveira, V. A. de; Lumbreiras, J. F.; Coelho, M. R.; Almeida, J. A. de; Cunha, T. J. F.; Oliveira, J. B. de. Sistema brasileiro de classificação de solos. 3.ed. Brasília: Embrapa, 2013. 353p. 
Scorvo Filho, J. D.; Martins, M. I. E. G.; Frasca-Scorvo, C. M. D. Instrumentos para análise da competitividade na piscicultura. In: Cyrino, J. E. P.; Urbinati, E. C.; Fracalossi, D. M. E; Castagnolli, N. (Eds.). Tópicos especiais em piscicultura de água doce tropical intensiva. Sao Paulo: TecArt, 2004. p. 517-533.

Sosa-Gómez, D. R.; Delpin, K. E.; Moscardi, F.; Nozaki, M. H. The impact of fungicides on Nomuraea rileyi (Farlow) Samson epizootics and on populations of Anticarsia gemmatalis Hübner (Lepidoptera: Noctuidae), on soybean. Neotropical Entomology, v. 32, n. 34, p. 287291, 2003. https://doi.org/10.1590/S1519-566X2003000200014.
Sosa-Gómez, D. R.; Moscardi, F. Retenção foliar diferencial em soja provocada por percevejos (Heteroptera: Pentatomidae). Anais da Sociedade Entomológica do Brasil, v. 24, n. 2, p. 401-404, 1995. https://www.researchgate.net/publication/262564115. 02 Ago. 2019.

Wille, P. E.; Pereira, B. A.; Wille, C. L.; Restelatto, S. S.; Boff, M. I. C.; Franco, C. R. Natural resistance of soybean cultivars to the soybean looper larva Chrysodeixis includens (Lepidoptera: Noctuidae). Pesquisa Agropecuária Brasileira, v. 52, n. 1, p. 1825, 2017. https://doi.org/10.1590/s0100-204×2017000100003. 